\title{
Determinant Factors and Working Capital Requirement
}

\author{
Muhammad Mehtab Azeem ${ }^{1} \&$ Akin Marsap ${ }^{1}$ \\ ${ }^{1}$ Department of Economics and administrative Science, Istanbul Aydin University, Turkey \\ Correspondence: Muhammad Mehtab Azeem, Istanbul Aydin University \& Francois Rabelais University, MBA, \\ Turkey. E-mail: mehtabazeem@yahoo.com
}

Received: January 9, 2015

doi:10.5539/ijef.v7n2p280
Accepted: January 14, 2015

Online Published: January 25, 2015

\begin{abstract}
The objective of the current study is to investigate the various factors determining the working capital requirements in Pakistani non-financial firms by taking into account different economic and financial variables relating to the business over a period of six years (2004-2009). The present study is anticipated to add to improve understanding the financial and non-financial firm related factors that form up working capital requirements of firms in the emerging markets like Pakistan.

This paper contributes the literature on the determinants of working capital management in non-financial firms in at least two ways. Firstly, it focuses on the Pakistani non-financial firms where only limited study has been conducted. Secondly, it confirms some of the findings of previous studies. For the purpose of sampling, only listed companies from Karachi Stock Exchange were selected. Here, the study will discuss about the data source, sample size and variables used in the study. Descriptive analysis, ANOVA, Correlation and Regression analysis will be applied on the panel data to see the relationship of different variables with Working Capital management.

The primary objective of this paper is to add toward a very important and often neglected part of financial management known as the Working Capital Management with reference to Pakistan. The study will see that what are the major factors those determine the Working Capital Requirements of Pakistani firms. This is achieved by developing a similar empirical model first used by Chiou and Cheng (2006) and the subsequent work of Nazir and Afza (2009).

Data used in this study were secondary data. All the Data except economic growth has been gathered from the publication of State Bank of Pakistan named as Balance Sheet Analysis of Joint Stock Companies listed on the Karachi Stock Exchange for the period of 2004-2009. This analysis is based on the published balance sheets of non-financial companies listed at Karachi Stock during 2009. For comparison purpose, the analysis of previous five years is also included in the publication which is ultimately very helpful for the users. The study used balanced panel data. This is used to calculate Working Capital Requirement, Operating Cycle, Operating Cash Flow, Return on Assets, Leverage and Growth.
\end{abstract}

More specifically, the key objectives are:

(i) To determine the factors influencing the working capital requirements for 385 Pakistani firms listed on Karachi Stock exchange.

(ii) To find out the relationships between working capital and different factors like size, leverage, economic growth, etc.

(iii) To draw conclusion about these determinants of working capital management requirements.

Keywords: working capital, management, determinant factors, non-financial firms

\section{Literature Review}

Shin and Soenen (1998) analyzed a large sample of listed American companies during 1975-1994 and found a strong negative relationship between Cash Conversion Cycle and corporate profitability. Weinraub and Visscher (1998) maidenly attempted to analyze the relative association between aggressive and conservative Working Capital practices. A Simple Regression Model was run that provide a great and significant negative relationship between industry asset and liabilities policies. They urged that whenever relative aggressive Working Capital assets policies were pursued it were balanced by relative conservative Working Capital financing policies. They also found that each industry had its own and relatively different management policies. 
Peter and Samulson (1998) worked on the accuracy of commonly held historical phenomena that the working capital position and level of economy activity interrelated with each other. A sample of 50 small firms was selected from the 200 desk small companies by applying t-test on the gathered data it was found that either there was economic slowdown or expansion the liquidity positions of the firms remained almost same that resultant in opposite of the commonly held phenomena.

Pandey and Parera (1999) worked on Working Capital Management policies and practices of private sector management companies listed in Colombo Stock Exchange. They found that mostly Sri Lankan firms were following informal working Capital policies. The result also showed that overall Working Capital policies and practices largely influence by company's size. Lyroudi and Lazaridis (2000) examined the relationship of Cash Conversion Cycle with the current and quick ratio of Greek food industry. By running the regression and correlation analysis they found a significant positive relationship between Cash Conversion Cycle and liquidity indicators (i.e. Quick and Current ratios). Enyi (2001) found that industry cash conversion cycle, company market power, its future sales and country risk largely determine the facets of working capital management.

Wang (2002) observed the relationship between 1) liquidity management and operating performance, and 2) liquidity management and corporate value of Japanese and Taiwanese firms. Pearson Correlation and Regression analysis (simple and multiple regressions) provided a strong negative and sensitive relationship between Cash Conversion Cycle and Return on Assets (ROA) and Return on Equity (ROE). There was significant lower Cash Conversion and higher ROA and ROE of the firms with $\mathrm{q}>1$ then the firm with $\mathrm{q} \leq 1$. The study also discovered that aggressive liquidity had linked with greater corporate value and improved operating performance.

Deloof (2003) looked into the relationship between Working Capital Management and Profitability of Belgium non-financial firms by taking the Cash Conversion Cycle as a broad determine of Working Capital Management. By using correlation analysis and Regression Model he found a significant relation between Gross Operating Income and number of days Account Receivable, Inventory and Account Payable. By these outcomes he proposed to managers to create value by dropping the number of days Account Receivable and Inventories to a rational level. He urged that his result supported the view that less profitable firms wait longer to pay their bills.

Howorth and Westhead (2003) analyzed the extent to which working capital management routines practiced in the small firms. They looked at 11 working capital routines. By using principal components and cluster analysis, the companies were grouped into four distinct types in term of managing working capital patterns and discussed the influences on amount and focus of working capital. For the purpose of revealing findings multinational logistic regression analysis was used which revealed that only those areas of working capital gained attraction of the small firms which could improve the marginal returns of the small firms.

Blazenko and Vandezande (2003) examined the consequences of stock out avoidance and market competition on corporate holding of finished goods. By using the regression analysis it was evident that large inventory holding is positively related to the expected sales. Moreover the findings resulted in a negative relationship between finished goods inventory holding and market competition. Fazzari and Petersen (2004) claimed to conduct study on that role of working capital which was neglected previously that is by taking into the account of fixed investment constraints on that. The study by using Regression analysis geared toward finding working capital investment negatively related to fixed investment. They also stated that previously the impacts of finance constraints were underestimated on growth and investment.

There exist a strong trade off between liquidity and profitability. Eljelly (2004) geared their study toward finding the relationship between profitability and liquidity which are the ultimate measures of current ratio and cash conversion cycle. Developing correlation and regression analysis they came to know that a significant negative relation between profitability and liquidity especially when there is high current ratio and longer cash conversion cycle. They also found that at the industry level cash conversion cycle more strongly affect profitability than current ratio. The Cash Conversion Cycle $(\mathrm{C} 2 \mathrm{C})$ is an imperative metric from the stance of supply chain management performance.

Poutziouris, Michaelas and Soufani (2005) conducted empirical investigation on the short term financial management of working capital in UK's SMEs by conducting primary and secondary research on the sample of 236 companies they found a direct association between growth and short term financial management practices of working capital management. They came to know that as companies grow, their short-term financial management practices also improved with that which resultant in reduce cost and enhance business performance. Banomyong (2005) tried to investigate and determine the Cash Conversion Cycle of an international Supply Chain. By developing a case study methodology he found that USA retailers invest a lot of money in inventory that should be avoided. 
Filbeck and Krueger (2005) presented imminent insight into the performance of firms across the key components of Working Capital Management. Their study based on the survey conducted by CFO magazine. They found that although Working Capital management variables are likewise across industry but the significant difference prevailed in the industries on the ways they manage their working capital.

Michalski (2007) identified the effects generated from operating risk associated with delaying payments by the purchaser and tried to identified the level of Account Receivable is positively related to both net working capital and cost of holding Account Receivable. The study conducted by Raheman and Nasir (2007) tried to find the relationship between Working Capital Management practice and its effects on profitability. They have adopted the Pearson's Correlation and Panel data Regression analysis. They established a strong negative relationship between the Cash Conversion Cycle (a measure of Working Capital) and profitability. There was also a strong negative association between liquidity and profitability. On the side of control variables; size of the firms had positive while leverage had a negative relationship with profitability.

Mehar (2007) focused only on first two components of cash conversion cycle that is inventory and Account Receivable. The three stages least square was applied on the sample data from which a negative relationship of Account Receivable was emerged with liquid assets and cost of production. The intention of the study conducted by Teruel and Solano (2007) was to present the experimental evidence of the effects of Working Capital Management on the profitability. These effects were tested by using Panel data Methodology by doing Univariate and Multivariate analysis. There was established a strong negative relationship of number of Account Receivable days and number of Inventory days with SMEs profitability but no significance found between Return on Assets and number of Account Payable days. They suggested SMEs to reduce Cash Conversion Cycle in order to enhance profitability.

Chowdhury and Amin (2007) attempted to assess the impact of overall working Capital policy on the industry's Profitability criteria. To achieve this both primary and secondary analysis were made by using Questionnaire Survey and Multiple Regression Models. By examining they came into the point that the value of Working Capital policy, financing of Working Capital and inventory holding (inventory turnover in days) have an important part in determining the level of Return on Assets. It also concluded that Return on Assets can be increased by pursuing aggressive policy toward Working Capital, at the same time suggested to adopt the conservative approach in financing the Current Assets.

The intention of the study conducted by Ganesan (2007) was to examine the relationship between Working Capital Management Efficiency and Profitability by using correlation and regression analysis. ANOVA analysis was also done for this purpose. The results indicated though Working Capital is negatively related to the Profitability but it had no significance in telecommunication equipment industry due to its different nature. Bhunia (2007) intended to find the efficiency level concerned with the management of short term liquidity in the Indian iron and steel ventures perspective. They found that efficiency of working capital rely on adequate short term position. To identify the weakness and its remedial measures we need to identify the adequate level of Working Capital Management.

Nazir and Afza (2009) have analyzed the factors determining the Working Capital Requirements of manufacturing firms. They have used panel data for the phase of 2004-2007 and run Ordinary Least Square (OLS) model on the determinants of Working Capital. They found that the Operating cycle and Stock market value positively related to Working Capital requirements but found leverage negatively related to the Working Capital requirements.

Appuhami (2008) have discussed the issue of impact of Capital expenditure on the Working Capital Management by using the data for a period of 2000-2005 of Thai firms. This empirical study via multiple regression analysis concluded that capital expenditure had a significant impact on Working Capital Management. They also established the firms' operating cash flow had a significant association with Working Capital Management. Ramachandran and Janakiraman (2009) investigated the relationship between Working Capital Management Efficiency and EBIT in the paper industry of India by using three indexes i.e. Performance Index (PI), Utilization Index (UI), and Efficiency Index (EI). By applying simple regression technique it was found that Working Capital measures (Account Receivable days, Cash Conversion Cycle, Inventory days, and Account Payable days) has a significant negative association with EBIT and indicated significant relationship between Working Capital Management Efficiency and EBIT.

Another study which was intends to establish the efficiency level in Working Capital Management and Return on Total Assets. Here two models were run on Istanbul Security Exchange Traded Firms by using Simple Regression Model. That resulted in a significant negative relationship among Cash Conversion Cycle, Net 
Working Capital level, Current ratio, Account Receivable period, Inventory period and Return on Total Assets (Sen \& Oruc, 2009). The aim of the study conducted by Zariyawati, Annuar, Taufiq and Rahim (2009) was to observe the relationship between Working Capital Management and firm profitability. By running the pooled regression analysis the study grant a strong negative relationship between Cash Conversion Cycle and firm profitability. They also proposed the managers to shorten the Cash Conversion Cycle at optimal level in order to create shareholder value.

In the Pakistani firms Nazir and Afza (2009) explored conventional relationship between Working Capital Management policies and a firm's profitability. The study applied Panel data Regression analysis to judge the impact of aggressive and conservative policies on the profitability of the firms. The study found that investor more considered the share of those firms that take on aggressive approach for the management of short term liabilities and also found a significant negative relationship between degree of aggressiveness of Working Capital policies and performance measures of firms. With other factors, the size of the firm also determines the firm profitability.

The objective of the study conducted by Uyar (2009) was to see the association of size of the firms and profitability with the Cash Conversion Cycle. For the purpose data was collected from the financial statement of listed corporation on the Istanbul Stock Exchange. Pearson Correlation and ANOVA analysis were used. The results showed that a significant negative correlation is existed between the Cash Conversion Cycle with firm's size and profitability. The paper offered to the firms an industry benchmark to weight up their Cash Conversion Cycle performance. Caballero, Teruel and Solano (2009) worked to investigate the determinants of Cash Conversion Cycle for the small and medium sized firms. While analyzing these SMEs, they came to know that each firm had a targeted length of Cash Conversion Cycle to which they tried to meet. For the time being they also made amendment in these targets. By developing the OLS estimation, it appeared that age and cash flow positively related to the Cash Conversion Cycle. The study also found that the companies with further growth chances, larger leverage, investment in fixed assets and return on assets usually followed an aggressive working Capital policy. The multinational companies have their own limitation and have different policies in term of working capital management.

Noreen, Khan and Abbas (2009) explored the question about the practices adopted by the multinational firms in handling of their international working management in Pakistan context. A primary research was conducted by the authors to identify the ways in which working capital managed. ANOVA was employed and seemed no difference in handling international cash management operation, sales operation and foreign exchange risk management wide to different sectors. Mathuva (2009) investigated the influence of working capital components on corporate profitability on a sample of 30 listed firms from Nairobi. For the purpose Pooled data for the period of 1993-2008 was collected. By utilizing Pooled OLS and Fixed Effect Models the result showed that there is highly significant negative relationship between profitability and days to collect Account Receivable. It was also found that day to convert inventory into sales and days to pay bills to creditors highly significantly related to profitability. The later showed that greater bargaining power with supplier should be there. On the whole it stated that there exit negative relationship between Cash Conversion Cycle and profitability.

Nobane and AlHajjar (2009) found that Return on Investment is significantly negatively related to cash conversion cycle and its first two components that are average collection period and inventory period but have positive relationship with average payment period. That's why the firm could improve profitability by shorting the first two and by lengthening the payment period.

Nobanee (2009) believed that profitability and market value have negative association with cash conversion cycle. He also took in account that shortening the inventory conversion period could increase holding cost, reducing collection period could result in loss of good customers and lengthening payment period could harm credit reputation of the firm. Nobane and AlHajjar (2009) found a negative relationship between profitability and operation cash flows.

Bargaining power, availability of internal finance, cost of financing and access to capital markets largely influenced on the working capital practices (Caballero, Teruel, \& Solano, 2009). Flope and Ajilore (2009) also worked on the relationship of Working Capital Management and Corporate Profitability. A sample of 50 Nigerian non-financial firms was taken and pool data regression was run for the period of 1996-2005. The result showed that a significant negative relationship existed among net profitability and Average Collection Period, Inventory Turnover in days, Average Payment Period and Cash Conversion Cycle.

Dong and $\mathrm{Su}$ (2010) attempted to examine the relationship between cash conversion cycle, its components and profitability. For this purpose secondary data of listed companies in Vietnam was collected and regression 
analysis was used. From which a strong negative relationship was found between cash conversion cycle and profitability. In the USA context Gill, Biger, and Mathur (2010) tried to expand the findings of Lazaridis and Tryfanidis regarding the relationship of Working Capital Management and Profitability. A sample of 88 Americans firms run in Weighted Least Square Model of Regression analysis. By this they came into the conclusion that a negative relationship exited between Account Receivable days and profitability while the relationship between Cash conversion Cycle and Profitability was positive. They provide a roam in their study for other researcher for further study in this context.

Hill, Kelly, and Highfield (2010) looked toward finding the behavior of net operating working capital. A descriptive statistics was used and fixed effect test (Regression model) was applied that revealed interesting findings. It was established that aggressive working capital tactics were practiced by those firms who were facing financial suffering, expensive outside financing, insecurity of sales and looking for sales growth while conservative working capital policies were for those who could rely on their own financial source and have superior market access.

For the purpose of sampling, only listed companies from Karachi Stock Exchange were selected. These companies showed a relative better performance during the year of 2009. Optimistic attitude has been seen in view of sales and profitability in sugar, paper \& board, and cement sector whereas a depression is observed in engineering, jute and other textile sectors. The combine paid up capital in term of ordinary share capital for all sectors has been reached at Rs. 439.99 billion in the year of 2009 while the working capital reached at Rs. 48.56 billion. In the same year the gross sales and profitability stood at Rs. 3431.92 billion and Rs. 196.99 billion respectively (source statistics department of SBP).

\section{Regression Model}

A Pooled Ordinary Least Square (OLS) regression model has been used to estimate the determinants of working capital. It is also called the constant coefficient model where both intercepts and slopes are constant; where the cross-section firm data and time series data are pooled together in a single column assuming that there is no significant cross-section or temporal effect. Based on previous empirical research the model is as follows:

$$
W C R \_T A=\alpha+\beta_{1} O C+\beta_{2} O C F \_T A+\beta_{3} E A+\beta_{4} G r w+\beta_{5} R O A+\beta_{6} L V R+\beta_{7} S I Z E+\varepsilon
$$

\section{Where:}

WCR_TA $=$ Working capital requirements deflated by total assets;

$\mathrm{OC}=$ Operating Cycle;

OCF_TA= Operating cash flows deflated by total assets;

$\mathrm{EA}=$ Level of economic activity i.e. real GDP growth rate;

Growth $=$ Sales Growth;

$\mathrm{ROA}=$ Return on assets;

$\mathrm{LVR}=$ Leverage as measured by debt to total assets ratio;

$\mathrm{SIZE}=$ Natural $\log$ of total assets as proxy for the size;

$\varepsilon=$ Error term.

Table 1. Summary of variables

\begin{tabular}{lll}
\hline \multicolumn{1}{l}{ Independent variable } & Proxy \\
\hline Working Capital requirements deflated by Total Assets(WCR_TA) & (Current Assets_Current liabilities)/Total Assets \\
\hline & \\
\hline Dependent variable & Proxy \\
\hline Operating Cycle & Nos. of days Account Receivable+ Nos. of days Inventory \\
Operating Cash Flow & (Net Profit before tax-tax provision-dividend +Depreciation for the year)/Total Assets \\
Level of Economic Activity & Real annual GDP growth rate \\
Growth & Sales1-Sales0/Sales0 \\
Return on Assets & Net income/Total Assets \\
Leverage & Total debt/total assets \\
Size & Natural logarithm of total assets \\
\hline
\end{tabular}




\section{Hypothesis 1}

The first hypothesis of this thesis is hereunder:

H01: There is no significant relationship between operating cycle and working capital requirements of Pakistani firms.

H11: There is a significant relationship between operating cycle and working capital requirements of Pakistani firms.

\section{Hypothesis 2}

The second hypothesis of the thesis is as follow:

H02: There is no significant relationship between operating cash flows and working capital requirements of Pakistani firms.

H12: There is a significant relationship between operating cash flows and working capital requirements of Pakistani firms.

\section{Hypothesis 3}

The Third hypothesis of the study is as follow:

H03: There is no significant relationship between level of economic activity and working capital requirements of Pakistani firms.

H13: There is a significant relationship between level of economic activity and working capital requirements of Pakistani firms.

\section{Hypothesis 4}

The Fourth hypothesis of the study is as under:

H04: There is no significant relationship between return on assets of Pakistani firms and working capital requirements.

H14: There is a significant relationship between return on assets of Pakistani firms and working capital requirements.

\section{Hypothesis 5}

The Fifth hypothesis of the study is hereunder:

H05: There is no significant relationship between sales growth of Pakistani firm and working capital requirements.

H15: There exists a significant relationship between sales growth and working capital requirements.

\section{Hypothesis 6}

The Sixth hypothesis of the study is as follow:

H06: There is no significant relationship between debts used by Pakistani firms and working capital requirements.

H16: There is a significant relationship between debts used by Pakistani firms and working capital requirements.

\section{Hypothesis 7}

The Seventh hypothesis of the study is as under:

H07: There is no significant relationship between size of Pakistani firms and working capital requirements.

H17: There is a significant relationship between the firm size and its working capital requirements.

Table 2 reports the summary of descriptive statistics for the variables of the sample of the study which form the foundation for the empirical examination. All the variables were calculated using the balance sheet (book) values. The book value was calculated due to unavailability of market values. In additions many of the firm specific variables are always based on the book values not on market like ROA. The total observations sums to $n=2310$ over the period 2004 to 2009. This analysis shows the mean and standard deviation of the variables included in the study. It also presents the minimum and maximum values a variable can attain. 
Table 2. Descriptive statistics

\begin{tabular}{|c|c|c|c|c|c|c|c|c|}
\hline & WCR & OC & OCF & EA & ROA & Growth & Leverage & Size \\
\hline \multicolumn{9}{|c|}{ Total Sample(N=2310) } \\
\hline Mean & 269.00 & 162.18 & 313.14 & 0.05 & 4.10 & 0.50 & 1.50 & 3.08 \\
\hline SD & 5405.86 & 678.37 & 2114.27 & 0.02 & 25.00 & 9.52 & 13.26 & 0.80 \\
\hline \multicolumn{9}{|c|}{ Means by Years( $N=385$ in each year $)$} \\
\hline 2004 & 194.60 & 145.83 & 302.10 & 0.09 & 5.30 & 0.30 & 1.26 & 2.95 \\
\hline 2005 & 576.10 & 196.28 & 383.82 & 0.06 & 6.01 & 1.22 & 1.28 & 3.02 \\
\hline 2006 & 296.00 & 140.10 & 360.90 & 0.07 & 6.80 & 0.31 & 1.30 & 3.07 \\
\hline 2007 & 356.52 & 133.33 & 357.17 & 0.04 & 3.20 & 1.00 & 1.66 & 3.11 \\
\hline 2008 & 112.04 & 155.21 & 222.00 & 0.01 & 2.10 & 0.20 & 1.70 & 3.15 \\
\hline 2009 & 78.70 & 202.07 & 258.83 & 0.04 & 1.23 & 0.06 & 1.75 & 3.16 \\
\hline \multicolumn{9}{|c|}{ SD by Years $(N=385$ in each year $)$} \\
\hline 2004 & 2521.18 & 384.00 & 1159.50 & 0.00 & 19.70 & 1.43 & 9.40 & 0.72 \\
\hline 2005 & 5968.82 & 1184.80 & 2244.00 & 0.00 & 20.41 & 17.60 & 10.06 & 0.75 \\
\hline 2006 & 3967.24 & 364.09 & 2035.81 & 0.00 & 27.43 & 0.68 & 9.85 & 0.77 \\
\hline 2007 & 4652.57 & 237.53 & 1882.85 & 0.00 & 23.24 & 15.14 & 15.20 & 0.84 \\
\hline 2008 & 5657.06 & 352.51 & 2717.00 & 0.00 & 29.52 & 0.81 & 15.77 & 0.86 \\
\hline 2009 & 8011.26 & 947.76 & 2325.27 & 0.00 & 27.50 & 1.30 & 17.04 & 0.86 \\
\hline \multicolumn{9}{|c|}{ Minimum by Year $(\mathrm{N}=385$ in each year $)$} \\
\hline 2004 & -20304.70 & 0.00 & -2510.00 & 0.10 & -123.20 & -1.00 & 0.00 & -1.00 \\
\hline 2005 & -19624.80 & 0.00 & -8734.60 & 0.06 & -71.90 & -1.00 & 0.00 & -1.00 \\
\hline 2006 & -26510.40 & 0.00 & -9918.50 & 0.07 & -146.00 & -1.00 & 0.00 & -1.00 \\
\hline 2007 & -33102.00 & 0.00 & -8855.40 & 0.03 & -133.00 & -1.00 & 0.00 & -1.00 \\
\hline 2008 & -51526.90 & 0.00 & -31972.60 & 0.01 & -200.00 & -1.00 & 0.00 & -1.00 \\
\hline 2009 & -65003.40 & 0.00 & -12465.20 & 0.04 & -200.00 & -1.00 & 0.00 & -1.00 \\
\hline \multicolumn{9}{|c|}{ Maximum by Year $(\mathrm{N}=385$ in each year) } \\
\hline 2004 & 33402.70 & 6622.14 & 15854.90 & 0.09 & 140.90 & 20.00 & 184.24 & 5.18 \\
\hline 2005 & 101098.30 & 2317.50 & 38633.30 & 0.06 & 302.60 & 337.86 & 197.62 & 5.12 \\
\hline 2006 & 50312.30 & 6468.17 & 32301.5 & 0.07 & 302.60 & 8.00 & 193.23 & 5.17 \\
\hline 2007 & 43900.80 & 2719.84 & 27867.80 & 0.04 & 205.20 & 296.70 & 296.64 & 5.17 \\
\hline 2008 & 41655.20 & 5475.00 & 19762.90 & 0.01 & 323.50 & 9.60 & 308.10 & 5.27 \\
\hline 2009 & 97689.20 & 17508.21 & 32454.10 & 0.04 & 323.50 & 24.14 & 333.16 & 5.25 \\
\hline
\end{tabular}

The dependent variable working capital requirements have a mean value 269.00 million rupees which is highest in 2005 and lowest in 2009 and standard deviation is of 5406 million rupees. The affirmative and high values of WCR show that companies are following a quite loose policy in respect of their working capital management. This is further confirmed by looking at operating cycle having average 162 days with standard deviation of 678 days. It mean value was also at its' highest in the same year of 2005 but lowest in 2007. Minimum time taken by a company to sell inventory and collect receivables from customers is 0 days while the maximum time in this respect is 17509 days which is very large time period to convert inventory into sales and collecting receivables from these sales.

To see the relationship between cash flows and working capital requirements, operating cash flows is used as explanatory variable. On average Operating Cash Flows are 313.00 million rupees which was highest in 2005 and lowest in 2008. The negative operating cash flow indicates that many of the firms have weak operating cash flows or operating losses.

On the other hand return on assets is varying across the period of the study. It has an average $4.10 \%$ of total assets with standard deviation of $25 \%$ of total assets. The year 2006 has the highest average return on assets of $6.80 \%$ while the year 2009 has the lowest return on assets of $1.23 \%$. The maximum value of for the return on asset is $323.50 \%$ of a company in a year while the minimum is $-200 \%$.

To check the growth of the firm and its role in determining working capital requirements, the sales growth is used as independent variable. The mean value of sales growth is $50 \%$ while the standard deviation is $952 \%$. The maximum value of sales growth for a company in a year is $33786 \%$ and in the same manner minimum is $-100 \%$.

It is pretended from the above statistics that in the same period, that is in 2005 when working capital 
requirements are its highest, the performance in term of ROA was also on 2nd highest (i.e. 6.01\%). In addition the sales growth is also at its highest level in the year of 2005 (i.e. 1.22\%). That period support the most of previous research which says there is no significant association between working capital policies (i.e. aggressive and conservative) and profitability, rather it confirmed general phenomenon that the following a loose policy regarding management of working capital will enhance the company's sales and profitability. It could be due to incompatible and unpredictable economic conditions of Pakistan. In the same way, to check the impact of level of economic activity in a country on determining the working capital requirements, real GDP growth rate is used. The average GDP growth rate in Pakistan is 5\% with standard deviation of $2 \%$. The maximum value of GDP growth rate in a year is $9 \%$ and minimum of $1 \%$. It can be seen that in the flourishing period of high GDP growth and economic activity, the working capital ratio is relatively high as judged against to other years.

To check the level of leverage a firm, a conventional measure of leverage (debt ratio) was used. The average current ratio for Pakistani firms is 1.50 with a standard deviation 13.26. To check the size of the firm and its influence on working capital requirements, natural logarithm of total assets is used as independent variable. The mean value of $\log$ of sales is 3.08 while the standard deviation is 0.80 . In the same way, the maximum value in a year is 5.25 and the minimum is -1.00 . On the other hand, variation in size was almost same in all years i.e. around 1 .

From the above statistics, it can be seen that there is a smooth and continuous enhancement in size over the period of study whereas leverage is also showing enhancement during the whole period that shows the firm prefer debt to increase their size. But the working capital requirements showed a mixed variation as both of above increased. When size and leverage was at their maximum that is in 2009 , the working capital requirements and return on assets were at their minimum that showed the negative effect of size and leverage on liquidity and profitability. That is due to high leverage. As the level of leverage increases, cost of debt will also increase which resultant in the lower level of liquidity and profitability.

Table 3. Correlation analyses

\begin{tabular}{|c|c|c|c|c|c|c|c|c|}
\hline & Variables & $\mathrm{OC}$ & $\mathrm{OCF}$ & EA & ROA & GRW & LEV & SZ \\
\hline $\mathrm{OC}$ & $\begin{array}{c}\text { Pearson Correlation } \\
\text { Sig. (2-tailed) }\end{array}$ & 1 & & & & & & \\
\hline \multirow[t]{2}{*}{$\mathrm{OCF}$} & Pearson Correlation & -.011 & 1 & & & & & \\
\hline & Sig. (2-tailed) & .583 & & & & & & \\
\hline \multirow[t]{2}{*}{ EA } & Pearson Correlation & -.005 & .014 & 1 & & & & \\
\hline & Sig. (2-tailed) & .812 & .505 & & & & & \\
\hline \multirow[t]{2}{*}{ ROA } & Pearson Correlation & -.025 & $.167 * *$ & $.061 * *$ & 1 & & & \\
\hline & Sig. (2-tailed) & .224 & .000 & .003 & & & & \\
\hline \multirow[t]{2}{*}{ GRW } & Pearson Correlation & -.010 & -.007 & .004 & -.011 & 1 & & \\
\hline & Sig. (2-tailed) & .620 & .723 & .854 & .582 & & & \\
\hline \multirow[t]{2}{*}{ LEV } & Pearson Correlation & -.014 & $-.012 * *$ & -.014 & $-.113 * *$ & -.004 & 1 & \\
\hline & Sig. (2-tailed) & .506 & .000 & .513 & .000 & .861 & & \\
\hline \multirow[t]{2}{*}{$\mathrm{SZ}$} & Pearson Correlation & $-.057 * *$ & $.237 * *$ & $-.078^{* *}$ & $.166^{* *}$ & .015 & $-.197 * *$ & 1 \\
\hline & Sig. (2-tailed) & .006 & .000 & .000 & .000 & .468 & .000 & \\
\hline
\end{tabular}

Table 4. Multi co-linearity test

\begin{tabular}{lcc}
\hline \multirow{2}{*}{ Independent Variables } & \multicolumn{2}{c}{ Co-linearity Statistics } \\
\cline { 2 - 3 } & Tolerance & VIF \\
\hline Operating Cycle & .996 & 1.004 \\
Operating Cash Flow & .924 & 1.082 \\
Level of Economic Activity & .987 & 1.013 \\
Return on Assets & .943 & 1.061 \\
Growth & .999 & 1.001 \\
Leverage & .951 & 1.051 \\
Size & .883 & 1.132 \\
\hline
\end{tabular}


Table 5. Autocorrelation test

\begin{tabular}{ccccc}
\hline $\mathrm{R}$ & R Square & Adjusted R Square & Std. Error of the Estimate & Durbin-Watson \\
\hline .999 & .998 & .998 & .558855099 & 2.081 \\
\hline
\end{tabular}

Table 6. Model summary

\begin{tabular}{cccc}
\hline $\mathrm{R}$ & $\mathrm{R}$ Square & Adjusted R Square & Std. Error of the Estimate \\
\hline .999 & .998 & .998 & .558855099 \\
\hline
\end{tabular}

Table 7. ANOVA analysis

\begin{tabular}{lccccc}
\hline & Sum of Squares & df & Mean Square & F & Sig. \\
\hline Regression & 404132.844 & 7 & 57733.263 & 184853.5 & $.000^{\mathrm{a}}$ \\
Residual & 718.958 & 2302 & .312 & & \\
Total & 404851.803 & 2309 & & & \\
\hline
\end{tabular}

Table 8. Model parameters

\begin{tabular}{|c|c|c|c|}
\hline \multirow{2}{*}{ Variables } & Standardized Coefficients & \multirow{2}{*}{$\mathrm{T}$} & \multirow{2}{*}{ Sig. } \\
\hline & Beta & & \\
\hline (Constant) & & 17.703 & .000 \\
\hline Operating Cycle & .000 & -.092 & .927 \\
\hline Operating Cash Flow & .002 & 1.744 & .081 \\
\hline Level of Economic Activity & -.001 & -1.265 & .206 \\
\hline Return on Assets & -.005 & -5.550 & .000 \\
\hline Growth & .001 & .990 & .322 \\
\hline Leverage & -1.001 & -1111.00 & .000 \\
\hline Size & -.006 & -5.953 & .000 \\
\hline
\end{tabular}

Note. a. Dependent Variable: Working Capital Requirement deflated by Total Assets.

\section{Conclusion and Recommendation}

In this study it is found that operating cycle, return on assets, leverage, size and level of economic activity is negatively related to working capital requirements of a firm whereas operating cash flows and sales growth are positively related to working capital requirements.

Regarding the hypotheses, it is concluded that the alternative hypothesis $\left(\mathrm{H}_{11}\right)$ that working capital requirements has a significant relationship with operating cycle is accepted; and therefore the $\left(\mathrm{H}_{01}\right)$ is rejected. In the same way, the 2nd alternative research hypothesis $\left(\mathrm{H}_{12}\right)$ is accepted that there is a significant relationship between operating cash flows and working capital requirements of Pakistani firms; therefore the null hypothesis $\left(\mathrm{H}_{02}\right)$ is rejected. Hence, the null research hypothesis $\left(\mathrm{H}_{03}\right)$ regarding the level of economic activity (measured in term of real GDP growth) is accepted; which postulating that there is no significant relationship between level of economic activity and working capital requirements; and therefore the alternative hypothesis $\left(\mathrm{H}_{13}\right)$ is rejected. This is interpreted as that there is no role of level of economic activity in determining the working capital requirements of the firms. The study also do accept the alternative hypothesis $\left(\mathrm{H}_{14}\right)$ concerning the return on assets as there is a significant relationship found between return on assets and working capital requirements; so the null hypothesis $\left(\mathrm{H}_{04}\right)$ is rejected. It is found that in Pakistan, return on assets significantly influence on the level of working capital requirements. From the 5th hypothesis of the study, the null hypothesis $\left(\mathrm{H}_{05}\right)$ is accepted; which claims that there is no significant relationship between sales growth and working capital requirements of Pakistani firms; so, the alternative hypothesis $\left(\mathrm{H}_{15}\right)$ is rejected here. By taking a look on sixth hypothesis results, it is found that the alternative hypothesis $\left(\mathrm{H}_{16}\right)$ should be accepted here; that means a significant relationship exist between working capital requirements and debts used by the firms. Therefore, the null hypothesis $\left(\mathrm{H}_{06}\right)$ should be rejected. This is inferred as that there is a big role of the level of debts used by a firm in determining their level of working capital requirements. The result of this study recommended for accepting the alternative hypothesis $\left(\mathrm{H}_{17}\right)$ relating to size of the firms as there is a significant relationship exist between size of the firm and working capital requirements; so the null hypothesis $\left(\mathrm{H}_{07}\right)$ is rejected here. So, it can be established that size of the firms also determines the level of working capital requirements of firms. These results are consistent with 
earlier study of Nazir and Afza (2009), Chiou and Cheng (2006), and Lamberson (1995). However, some of results are also in contradiction to these studies. This could be due to special nature of the developing market of Pakistan.

\section{References}

Appuhami, B. R. (2008). The Impact of Firms' Capital Expenditure on Working Capital Management: An Empirical Study across Industries in Thailand. International Management Review, 4(1), 8-21.

Banomyong, R. (2005). Measuring the Cash Conversion Cycle in an International Supply Chain. Annual Logistics Research Network (LRN) Conference Proceedings (pp. 29-34). Plymouth, UK. Retrieved from http://www.bus.tu.ac.th/usr/Ruth/file/C2C\%20LRN\%202005.pdf

Banos-Caballero, S., Garcia-Teruel, P. J., \& Martinez-Solano, P. (2009). How do market imperfections affect working capital management?

Banos-Caballero, S., Garcia-Teruel, P. J., \& Martinez-Solano, P. (2010). Working capital management in SMEs. Accounting and Finance, (50), 511-527. http://dx.doi.org/10.1111/j.1467-629X.2009.00331.x

Berger, A., \& Udell, G. (2001). The ability of banks to lend to information-ally opaque small business. Journal of Banking and Finance, (25), 2127-2167. http://dx.doi.org/10.1016/S0378-4266(01)00189-3

Bhunia, A. (2007). Liquidity Management Of Public Sector Iron And Steel Enterprises In India. Vidyasagar University Journal of Commerce, 12, 85-98. Retrieved from http://14.139.211.206:8080/jspui/handle/123456789/387

Blazenko, G. W., \& Vandezande, K. (2003). Corporate holding of finished goods inventories. Journal of Economics and Business, (55), 255-266. http://dx.doi.org/10.1016/S0148-6195(03)00023-7

Chiou, J., \& Cheng, L. (2006). The Determinants of Working Capital Management. Journal of American Academy of $\quad$ Business, $10(1), \quad 149-155 . \quad$ Retrieved from http://papers.ssrn.com/sol3/papers.cfm?abstract_id=2195245

Chowdhury, A., \& Amin, M. M. (2007). Working Capital Management Practiced In Pharmaceutical Companies Listed In Dhaka Stock Exchange. Brac University Journal, 4(2), 75-86.

Deloof, M., \& Jeger, M. (1996). Trade Credit, Product Quality, and Intra group Trade: Some European Evidence. Financial Management, 25(3), 945-968. http://dx.doi.org/10.2307/3665806

Dong, H. P., \& Su, J. T. (2010). The Relationship between Working Capital Management and Profitability: A Vietnam Case. International Research Journal of Finance and Economics, 49, 62-71. Retrieved from http://www.researchgate.net/publication/228618956 The Relationship between Working Capital Manag ement_and_Profitability_A_Vietnam_Case

Enyi, E. P. (2001). Applying Relative Solvency To Working Capital Management: The Break-Even Approach.

Filbeck, G., \& Krueger, T. M. (2005). An Analysis of Working Capital Management Results Across Industries. Mid-American Journal of Business, 20(2), 11-18. http://dx.doi.org/10.1108/19355181200500007

Flope, O., \& Ajilore, O. (2009). Working Capital Management and Corporate Profitability: evidence from panel data analysis of selected quoted companies in Nigeria. Research Journal of Business Management, (3), 7384. Retrieved from http://www.scialert.net/abstract/?doi=rjbm.2009.73.84

Ganesan, V. (2007). An Analysis Of Working Capital Management Efficiency In Telecommunication Equipment Industry. Rivier Academic Journal, 3(2), 1-10.

Garcia-Teruel, P. J., \& Martinez-Solano, P. (2007). Effects of working capital management on SME profitability. International Journal of Managerial, 3(2), 164-177. http://dx.doi.org/10.1108/17439130710738718

Gentry, J. A., Vaidyanthan, R., \& Lee, H. W. (1990). A Weighted Cash Conversion Cycle. Financial Management, 19(1), 90-99. http://dx.doi.org/10.2307/3666040

Ghosh, S. K., \& Maji, S. G. (2003). Working Capital Management Efficiency: A study on the Indian cement industry. The Institute of Cost and Works Accountants of India. Retrieved from http://www.icwai.org/icwai/knowledgebank/fm47.pdf

Gill, A., Biger, N., \& Mathur, N. (2010). The Relationship Between Working Capital Management And Profitability: Evidence From The United States. Business and Economics Journal, 1-9. http://astonjournals.com/manuscripts/Vol2010/BEJ-10_Vol2010.pdf 
Hall, C. (2002). Total Working Capital Management. AFP Exchange, 22(6), 26-32.

Harris, A. (2005). Working Capital Management: Difficult, but Rewarding. Financial Executive, 21(4), $52-53$.

Hill, M. D., Kelly, G. W., \& Highfield, M. J. (2010). Net Operating Working Capital Behavior: A First Look. Financial Management, 783-805. http://dx.doi.org/10.1111/j.1755-053X.2010.01092.x

Horne, V., \& Jose, C. (1969). Risk-return analysis of a firm working capital. The Engineering Economist, 14, 71-89. http://dx.doi.org/10.1080/00137916908928796

Horrigan, J. O. (1965). Some empirical base of financial ratios analysis. The Accounting Review, 558-568.

Howorth, C., \& Westhead, P. (2003). The focus of working capital management in UK small firms. Management Accounting Research, 1(14), 94-111. http://dx.doi.org/10.1016/S1044-5005(03)00022-2

Jarvis, R., Kitching, J., Curran, J., \& Lightfoot, G. (1996). The Financial Management of Small Firms: An Alternative Perspective. ACCA Research Report No. 49.

John, T. A. (1993). Accounting Measures of Corporate Liquidity, Leverage, and Costs of Financial Distress. Financial Management Association, 22(3), 91-100. http://dx.doi.org/10.2307/3665930

Jordan, J., Lowe, J., \& Taylor, P. (1998). Strategy and financial policy in UK small firms. Journal of Business Finance and Accounting, 25, 1-27. http://dx.doi.org/10.1111/1468-5957.00176

Jose, M. C. L., \& John, L, S. (1996). Corporate Returns and Cash Conversion Cycle. Journal of Economics and Finance, 20(1), 33-46. http://dx.doi.org/10.1007/BF02920497

Joshi, P. V. (1995). Working Capital Management under Inflation (1st ed., pp. 20-93). Anmol Publishers.

Kargar, J., \& Blumenthal, R. A. (1994). Leverage Impact of Working Capital in Small Businesses. TMA Journal, 14(6), 46-53.

Lamberson, M. (1995). Changes in Working Capital of Small Firms in Relation to Changes in Economic Activity. Mid-American Journal of Business, 10(2), 45-50. http://dx.doi.org/10.1108/19355181199500015

Lazaridis, I., \& Tryfonidis, D. (2006). The relationship between working capital management and profitability of listed companies in the Athens Stock Exchange. Journal of Financial Management and Analysis, 19(1), 111. Retrieved from http://papers.ssrn.com/sol3/papers.cfm?abstract_id=931591

Long, M. S., Malitz, I. B., \& Ravid, S. A. (1993). Trade Credit, Quality Guarantees, and Product Marketability. Financial Management, 22(4), 117-127. http://dx.doi.org/10.2307/3665582

Luo, M. M., Lee, J. J., \& Hwang, Y. (2009). Cash Conversion Cycle, Firm Performance and Stock Value. Retrieved from http://papers.ssrn.com/sol3/papers.cfm?abstract_id=2342460

Lyroudi, K., \& Lazaridis, J. (2000). The Cash Conversion Cycle and Liquidity Analysis of The Food Industry in Greece.

Majumdar, C. (1996). Borrowing as a Source of Financing Working Capital in The Corporate Sector in India: An Empirical Analysis. Finance India, 10(1), 103-107.

Marc, D. (2003). Does Working Capital Management Affect Profitability of Belgian Firms? Journal of Business Finance \& Accounting, 30(3)\&(4), 573-587.

Mathuva, D. M. (2009). The Influence of Working Capital Management Components on Corporate Profitability: A Survey of Kenyan Listed Firms. Research Journal of Business Management, 1-11.

Meszek, W., \& Polewski, M. (2006). Certain aspects of Working Capital in a construction company. Technological and Economic Development of Economy, XII(3), 222-226. Retrieved from http://www.tandfonline.com/doi/pdf/10.1080/13928619.2006.9637745

Nazir, M. S., \& Afza, T. (2008). On The Factor Determining Working Capital Requirements. Proceedings of $A S B B S, 15(1), 293-301$.

Nazir, M. S., \& Afza, T. (2009). Impact of Aggressive Working Capital Management Policy on Firms' Profitability. The IUP Journal of Applied Finance, 15(8), 19-29. Retrieved from http://www.ciitlahore.edu.pk/Papers/252-8589041889548213308.pdf

Niskanen, J. (2006). The Determinants of Corporate Credit Trade Policies in a Bank-dominated Financial Environment: the Case of Finnish Small Firms. European Financial Management, 12(1), 81-102. http://dx.doi.org/10.1111/j.1354-7798.2006.00311.x 
Nobanee, H. (2009). Working Capital Management and Firm's Profitability: An Optimal Cash Conversion Cycle. Retrieved http://www.researchgate.net/publication/228252595_Working_Capital_Management_and_Firm\%27s_Profi tability_An_Optimal_Cash_Conversion_Cycle

Nobanee, H., \& AlHajjar, M. (2009a). A Note On Working Capital Management And Corporate Profitability of Japanese Firms.

Nobanee, H., \& AlHajjar, M. (2009b). Working Capital Management, Operating Cash Flow and Corporate Performance.

Nobanee, H., AlShattarat, W. K., \& Haddad, A. E. (2009). Optimizing Working Capital Management.

Noreen, U., \& Khan, S. K. (2009). International Working Capital Practices in Pakistan. International Research Journal of Finance and Economics, (32), 160-170.

Nunn, K. (1981). The strategic determinants of working capital: a product-line perspective. Journal of Financial Research, 4, 207-219. http://dx.doi.org/10.1111/j.1475-6803.1981.tb00604.x

Okeke, B. (2000). Financial Management in Cooperatives. Journal of Management Sciences, 3(2).

Oruc, E., \& Sen, M. (2009). Relationship between Efficiency Level of Working Capital Management and Return on Total Assets in Ise. International Journal of Business and Management, 4(10), 109-114. Retrieved from http://webcache.googleusercontent.com/search?q=cache:GMgBHThKaQAJ:www.journalofbusiness.org/in dex.php/GJMBR/article/viewFile/1350/1257+\&cd=2\&hl=tr\&ct=clnk\&gl=tr

Osisioma, B. C. (1997). Sources and Management of Working Capital. Journal of Management Sciences, 2(J).

Padachi, K. (2006). Trends in Working Capital Management and its Impact on Firms' Performance: An Analysis of Mauritian Small Manufacturing Firms. International Review of Business Research Papers, 2(2), 45-58.

Pandy, I., \& Parera, K. (1997). Determinants of Effective Working Capital Management: A discriminant analysis approach.

Peel, M. J., Wilson, N., \& Howorth, C. A. (2000). Late payment and credit management in the small firm sector: some empirical evidence. International Small Business Journal, 18(2), 17-37. http://dx.doi.org/10.1177/0266242600182001

Petersen, M., \& Rajan, G. (1997). Trade Credit: Theories and Evidence. Review of Financial Studies, 10(3), 661691. http://dx.doi.org/10.1093/rfs/10.3.661

Petersen, M., \& Rajan, R. (1995). The effect of credit market competition on lending relationships. Quarterly Journal of Economics, 110, 407-443. http://dx.doi.org/10.2307/2118445

Pike, R., \& Nam, S. C. (2001). Credit Management: An Examination of Policy Choices, Practices and Late Payment in UK Companies. Journal of Business Finance \& Accounting, 28(78), 10-13.

Poutziouris, P., Michaelas, N., \& Soufani, K. (2005). Short-Term Financial Management of Working Capital in Small-Medium Sized Enterprises.

Raheman, A., \& Nasr, M. (2007). Working Capital Management And Profitability: Case of Pakistani Firms. International Review of Business Research Papers, 3(1), 279-300.

Ramachandran, A., \& Janakiraman, M. (2009). The Relationship between Working Capital Management Efficiency and EBIT. Managing Global Transitions, 7(1), 61-74.

Sagan, J. (1955). Toward A Theory of Working Capital Management. The Journal of Finance, 10(2), 9-121. http://dx.doi.org/10.1111/j.1540-6261.1955.tb01259.x

Salawu, R. (2006). Industry Practice and Aggressive Conservative Working Capital Policies in Nigeria. European Journal of Scientific Research, 13(3), 294-304.

Shah, A. S., \& Sana, A. (2006). Impact of Working Capital Management on the Pofitability of Oil and Gas Sector of Pakistan. European Journal of Scientific Research, 15(3), 301-307.

Shin, H. H., \& Soenen, L. (1998). Efficiency of working capital management and corporate profitability. Financial Practice and Education, 8(2), 37-45.

Vishnani, S. (2007). Impact of Working Capital Management Policies on Corporate Performance: An Empirical Study. The Management Acc., ICWAI, 748-750. 
Wang, Y. J. (2002). Liquidity management, operating performance, and corporate value: evidence from Japan and Taiwan. Journal of Multinational Financial Management, 12, 159-169. http://dx.doi.org/10.1016/S1042-444X(01)00047-0

Weinraub, H. J., \& Visscher, S. (1998). Industry Practice Relating To Aggressive Conservative Working Capital Policies. Journal of Financial and Strategic Decisions, 11(2), 11-18.

Wilner, B. S. (2000). The exploitation of relationships in financial distress: the case of trade credit. Journal of Finance, 55, 153-178. http://dx.doi.org/10.1111/0022-1082.00203

Zainudin, N. (2006). Liquidity-Profitability Tradeoff: Is it evident among Malaysian SMEs? IJMS, 13(2), 107118.

Zariyawati, M. A., Annuar, M. N., Taufiq, H., \& Abdul Rahim, A. S. (2009). Working capital management and corporate performance: Case of Malaysia. Journal of Modern Accounting and Auditing, 5(11), 47-54.

Zhou, D. C. (1995). The impact of the change of business cycle on financial ratio in manufacturing industry. Journal of the Bank of Taiwan, 46(2), 67-98.

\section{Copyrights}

Copyright for this article is retained by the author(s), with first publication rights granted to the journal.

This is an open-access article distributed under the terms and conditions of the Creative Commons Attribution license (http://creativecommons.org/licenses/by/3.0/). 